\title{
Nomadic behaviour of the highly migratory olive ridley sea turtle Lepidochelys olivacea in the eastern tropical Pacific Ocean
}

\author{
Pamela T. Plotkin* \\ Cornell University, Office of Sponsored Programs, 373 Pine Tree Road, Ithaca, New York 14850, USA
}

\begin{abstract}
I studied the post-reproductive migrations of 30 male and female olive ridley sea turtles Lepidochelys olivacea in the eastern tropical Pacific Ocean (ETP) using satellite telemetry. Long-term data revealed that turtles were widely distributed in the pelagic zone from Mexico to Peru and lacked migratory corridors. Turtles migrated long distances, swam continuously, displayed no fidelity to specific feeding habitats, and were nomadic. An El Niño occurred in the middle of the study, and turtle migration patterns changed in response. ETP olive ridleys likely evolved migratory flexibility to adapt to the frequent and unpredictable environmental change characteristic of their large dynamic marine ecosystem. This suggests that ETP olive ridleys may be less vulnerable to the impacts of climate change than other sea turtle species.
\end{abstract}

KEY WORDS: Lepidochelys olivacea Eastern tropical Pacific $\cdot$ Satellite telemetry $\cdot$ Nomadic Highly migratory $\cdot$ El Niño

\section{INTRODUCTION}

Long-distance animal migrations are generally resource-driven, with migrants travelling between or among established locations at regular or seasonal intervals. When resources are predictable in time and space, migratory patterns are relatively static, whereas when resource distribution and abundance are variable and unpredictable, animals tend to have movement patterns that parallel their dynamic environment (Roshier \& Reid 2003). Compensating for fluctuations in dynamic environments requires migratory adaptability, a trait that has evolved across multiple taxa (Alerstam et al. 2003) and has led to a rich diversity of migratory behaviours. The most flexible migratory behaviour is nomadism, broadly defined as the purposeful movement from a changing and unsuitable environment to other locations with no predetermined endpoint. Nomadism likely evolved to maximise fitness in unpredictable environments and is well-represented across diverse taxa, including invertebrates (Franks \& Fletcher 1983), fish (Klimley et al. 2003), rep- tiles (Plotkin 2003), birds (Dean 1997) and mammals (McCullough 1985).

Sea turtles are long-distance migrants that inhabit dynamic ocean environments and predictably should display migratory flexibility. Most species undertake seasonal return migrations, broadly defined as migrations between established breeding grounds and feeding areas at regular and somewhat predictable intervals (Plotkin 2003). For many years this generalisable model was advanced to characterise all sea turtle migrations. However, research conducted during the past decade has led to a paradigm shift, and the one general sea turtle migration model is now obsolete. Several key studies have revealed migratory flexibility, interspecific and intraspecific variation (Luschi et al. 2003, Plotkin 2003, Hays et al. 2004, Godley et al. 2008) and a strong relationship between patterns of movement and the distribution of key resources (e.g. Craig et al. 2004, Troëng et al. 2005a,b, Broderick et al. 2007, Morreale et al. 2007, Witt et al. 2007, Seminoff et al. 2008).

I studied the migratory behaviour of adult olive ridleys in the eastern tropical Pacific Ocean (ETP) 
from 1990 to 1994. Colleagues and I previously reported that the migrations of females are not socially facilitated, but often appear to be so because of a high degree of spatio-temporal overlap of individuals responding to the same environmental cues (Plotkin et al. 1995). We also previously described the reproductive and developmental synchrony of females during the internesting period (Plotkin et al. 1997) and the breeding ground behaviour and movements of males (Plotkin et al. 1996). Here I characterise the post-reproductive migrations of all turtles tracked, and the relationship between their migration routes and oceanographic features that characterise the ETP.

\section{MATERALS AND METHODS}

I attached satellite transmitters to 21 female and 9 male olive ridleys between 1990 and 1993. Most females were captured on Nancite Beach, Costa Rica $\left(10.806^{\circ} \mathrm{N}, 85.699^{\circ} \mathrm{W}\right)$ during an 'arribada', the synchronous nesting of large numbers of turtles unique to the genus Lepidochelys (Bernardo \& Plotkin 2007). When arribada turtles were unavailable, I attached transmitters to solitary nesting turtles, or to females captured in the Gulf of Papagayo, adjacent to Nancite Beach. Male ridleys were captured in these same waters. One male was captured during a research cruise in the ETP, several hundred $\mathrm{km}$ southwest of Panama (Owens 1993). Details of transmitter attachment methods used in this study are provided in Plotkin (1998). I used 2 different models of transmitters during this study: Telonics models ST-3 and ST-6. Turtle movements were monitored by the Argos Data Collection and Location System onboard 2 NOAA Tiros-N satellites that passed over the study area approximately 3 to 4 times daily (Argos 1984). Satellites received transmissions every 54 to 63 s only when a transmitter was turned on, a satellite was overhead and a turtle was at the ocean's surface. To increase the probability of long-term data collection, transmitters were programmed to transmit every second or third day (transmitter duty cycles were: $10 \mathrm{~h}$ on, $50 \mathrm{~h}$ off; $10 \mathrm{~h}$ on, $74 \mathrm{~h}$ off; or $8 \mathrm{~h}$ on, $52 \mathrm{~h}$ off). A description of the data received and the method used to filter data (i.e. reject incorrect or questionable data) is detailed in Plotkin (1998).

I calculated the minimum distance travelled for each turtle based on the sum of the straight line distances between consecutive locations, using a program written in Basic by T. Amos, University of Texas Marine Science Institute. I also calculated the rate of movement ( $\mathrm{ROM} ; \mathrm{km} \mathrm{h}^{-1}$ ) between consecutive locations and the mean ROM for each turtle. Statistical analysis was conducted using JMP (SAS Institute, www.jmp.com). Maps were created using the Maptool program, a product of www.seaturtle.org.

\section{RESULTS}

Individual turtles were tracked for periods ranging from 6 to 779 d (Table 1). Data for 3 turtles are not included beyond that presented in Table 1 because transmissions ceased before their post-reproductive migration (7672b and 7676), or because I removed the transmitter intentionally when the turtle was recaptured nesting (7672a). Some of the data from an additional pair of turtles $(7670 \mathrm{~b}$ and $7671 \mathrm{~b})$ are not included in the analyses of transmitter duration, distance travelled and ROM because they are believed to have been captured and brought on board a vessel during their migration. For both turtles, transmitter pressure sensors no longer recorded changes in pressure (i.e. turtles were not diving) and their ROM increased significantly at and beyond their suspected point of capture. Excluding transmitter duration data for these 5 turtles, the mean \pm SD tracking duration for the remaining 25 turtles was $236 \pm 142$ d, nearly 8 mo. Three turtles were tracked for more than $1 \mathrm{yr}$, and one of the 3 was tracked for more than 2 yr using 2 different transmitters.

\section{Migration routes and patterns}

The migration routes of turtles from their breeding grounds in Costa Rica spanned nearly the entire ETP. The most distant points of the migratory range included the Gulf of Tehuantepec, Mexico, in the north, south across the Equator into Peruvian waters, and over $4000 \mathrm{~km}$ due west of Costa Rica. Turtles migrated within the territorial and/or international waters of Mexico, Guatemala, El Salvador, Honduras, Nicaragua, Costa Rica, Panama, Colombia, Ecuador and Peru. Most turtles migrated in deep pelagic waters, from several hundred $\mathrm{km}$ to several thousand $\mathrm{km}$ from land. A few turtles migrated closer to shore (within tens of $\mathrm{km}$ from land), but were still swimming in deep water. There were no apparent migratory corridors and no common feeding grounds observed. In fact, there were no specific feeding grounds identified for any individual turtle. Turtles were wide-ranging and on the move almost all the time, with the exception of brief stops that lasted several days to a few weeks. Most turtles never returned to a location visited previously. Only 1 turtle was not wide-ranging (7674a; see Figs. S1 to S3 in the Supplement at www.intres.com/articles/suppl/n013p033_supp.pdf). 
Table 1. Lepidochelys olivacea. Olive ridley turtle transmitter ID and model, gender, capture location, behaviour at time of capture, date of deployment and last transmission and number of days between deployment and last transmission. GP: Gulf of Papagayo; Arribada: nesting during 'arribada'; Mounted: captured while mounted to a female; Solitary: solitary nester; Swimming: captured while swimming

\begin{tabular}{|c|c|c|c|c|c|c|c|}
\hline ID no. & $\begin{array}{c}\text { Transmitter } \\
\text { model }\end{array}$ & Gender & $\begin{array}{l}\text { Capture } \\
\text { location }\end{array}$ & Behaviour & $\begin{array}{c}\text { Date } \\
\text { deployed }\end{array}$ & $\begin{array}{c}\text { Date last } \\
\text { transmission }\end{array}$ & $\begin{array}{l}\text { No. of } \\
\text { days }\end{array}$ \\
\hline 7667 & ST-3 & F & GP & Swimming & 13 Sep 90 & 6 Apr 91 & 205 \\
\hline 7668 & ST-3 & F & Nancite & Arribada & 18 Sep 90 & 8 Mar 91 & 171 \\
\hline 7669 & ST-3 & F & Nancite & Arribada & 18 Sep 90 & 25 Dec 90 & 98 \\
\hline $7670 a$ & ST-3 & $\mathrm{F}$ & Nancite & Arribada & 18 Sep 90 & 22 Apr 91 & 216 \\
\hline $7670 b^{a}$ & ST-6 & $\mathrm{F}$ & Nancite & Solitary & 21 Nov 92 & 22 Apr 93 & 152 \\
\hline $7671 a$ & ST-3 & $\mathrm{F}$ & Nancite & Arribada & 18 Sep 90 & 25 Dec 90 & 98 \\
\hline $7671 b^{a}$ & ST-6 & M & GP & Mounted & 12 Jul 93 & 18 Aug 93 & 37 \\
\hline $7672 a$ & ST-3 & $\mathrm{F}$ & Nancite & Arribada & 18 Sep 90 & 25 Nov 90 & 68 \\
\hline $7672 b$ & ST-3 & M & GP & Mounted & 12 Aug 91 & 7 Sep 91 & 26 \\
\hline $7672 \mathrm{c}$ & ST-6 & M & GP & Mounted & 14 Jul 93 & 16 Mar 94 & 245 \\
\hline $7673 a$ & ST-3 & $\mathrm{F}$ & Nancite & Arribada & 18 Sep 90 & 6 Feb 91 & 141 \\
\hline $7673 b$ & ST-6 & M & GP & Mounted & 14 Jul 93 & 6 Dec 93 & 145 \\
\hline $7674 a$ & ST-3 & $\mathrm{F}$ & GP & Swimming & 20 Nov 90 & 11 Mar 91 & 111 \\
\hline $7674 b$ & ST-6 & M & GP & Mounted & 14 Jul 93 & 5 May 94 & 295 \\
\hline $7675 a^{b}$ & ST-3 & $\mathrm{F}$ & GP & Swimming & 16 Nov 90 & 1 Nov 91 & 350 \\
\hline $7675 b$ & ST-3 & M & ETP & Swimming & 25 Mar 93 & 22 Sep 93 & 181 \\
\hline 7676 & ST-6 & M & GP & Mounted & $15 \mathrm{Jul} 93$ & 21 Jul 93 & 6 \\
\hline 7677 & ST-3 & $\mathrm{F}$ & Nancite & Solitary & 15 Nov 90 & 2 Mar 92 & 473 \\
\hline $7678 a$ & ST-3 & $\mathrm{F}$ & Nancite & Arribada & 31 Oct 91 & 1 Mar 92 & 122 \\
\hline $7678 b$ & ST-6 & M & GP & Mounted & 15 Jul 93 & 7 May 94 & 296 \\
\hline 7679 & ST-3 & $\mathrm{F}$ & Nancite & Arribada & 1 Nov 91 & 25 Apr 92 & 176 \\
\hline $7680 a$ & ST-3 & $\mathrm{F}$ & Nancite & Arribada & 5 Sep 91 & 7 May 92 & 245 \\
\hline $7680 \mathrm{~b}$ & ST-6 & M & GP & Mounted & 18 Jul 93 & 16 Feb 94 & 213 \\
\hline $7681^{b}$ & ST-3 & $\mathrm{F}$ & Nancite & Arribada & 1 Nov 91 & 3 Jan 93 & 429 \\
\hline 7682 & ST-3 & $\mathrm{F}$ & Nancite & Arribada & 1 Nov 91 & 16 Apr 92 & 167 \\
\hline 7683 & ST-3 & $\mathrm{F}$ & Nancite & Arribada & 5 Sep 91 & 22 May 92 & 260 \\
\hline 7685 & ST-3 & $\mathrm{F}$ & Nancite & Arribada & 1 Nov 91 & 9 Nov 92 & 374 \\
\hline 7686 & ST-3 & $\mathrm{F}$ & Nancite & Arribada & 4 Sep 91 & 15 May 92 & 254 \\
\hline 7687 & ST-3 & $\mathrm{F}$ & Nancite & Arribada & 5 Sep 91 & 8 Mar 92 & 185 \\
\hline 7688 & ST-3 & $\mathrm{F}$ & Nancite & Arribada & 5 Sep 91 & 21 Mar 92 & 198 \\
\hline 7689 & ST-3 & $\mathrm{F}$ & Nancite & Arribada & 5 Sep 91 & 7 May 92 & 245 \\
\hline
\end{tabular}

No apparent gender-specific differences were observed. The migratory patterns of female and male olive ridleys were strikingly similar. Both females and males swam more or less continuously, occupied oceanic waters and displayed no fidelity to any particular area. There was a clear distinction between the migratory patterns of females tracked during the first year (1990-1991) and females tracked during the second year (1991-1992; Fig. 1). Females tracked during the first year $(n=9)$ were more widely dispersed throughout the ETP during their migrations, swimming north, west and south of Costa Rica. Females tracked during the second year $(\mathrm{n}=11)$ migrated primarily north and west of Costa Rica, from the Gulf of Tehuantepec, Mexico, south to the Gulf of Papagayo, Costa Rica. Males tracked from Costa Rica in 1993 (n =6) migrated north, west, and south of Costa Rica (see Fig. S4 in the supplement at www.int-res.com/ articles/suppl/n013p033_supp.pdf). One additional male turtle captured at sea during a research cruise migrated northwest of his capture location, remaining in deep oceanic waters far from land (see Fig. S4).

\section{Distances travelled and rates of movement}

The minimum distance travelled by females during both years ranged from $438 \mathrm{~km}$ in $98 \mathrm{~d}$ to $10650 \mathrm{~km}$ in $779 \mathrm{~d}$ (mean $\pm \mathrm{SD}=3669 \pm 2007 \mathrm{~km}, \mathrm{n}=20$; Table 2). The minimum distance travelled by males ranged from $1173 \mathrm{~km}$ in $245 \mathrm{~d}$ to $3914 \mathrm{~km}$ in $296 \mathrm{~d}$ (mean $\pm \mathrm{SD}=$ $2379 \pm 931 \mathrm{~km}, \mathrm{n}=6$; Table 2). The minimum distance travelled by females during the first year (1990-1991; mean $\pm \mathrm{SD}=2751 \pm 2217 \mathrm{~km}, \mathrm{n}=9$ ) was significantly 

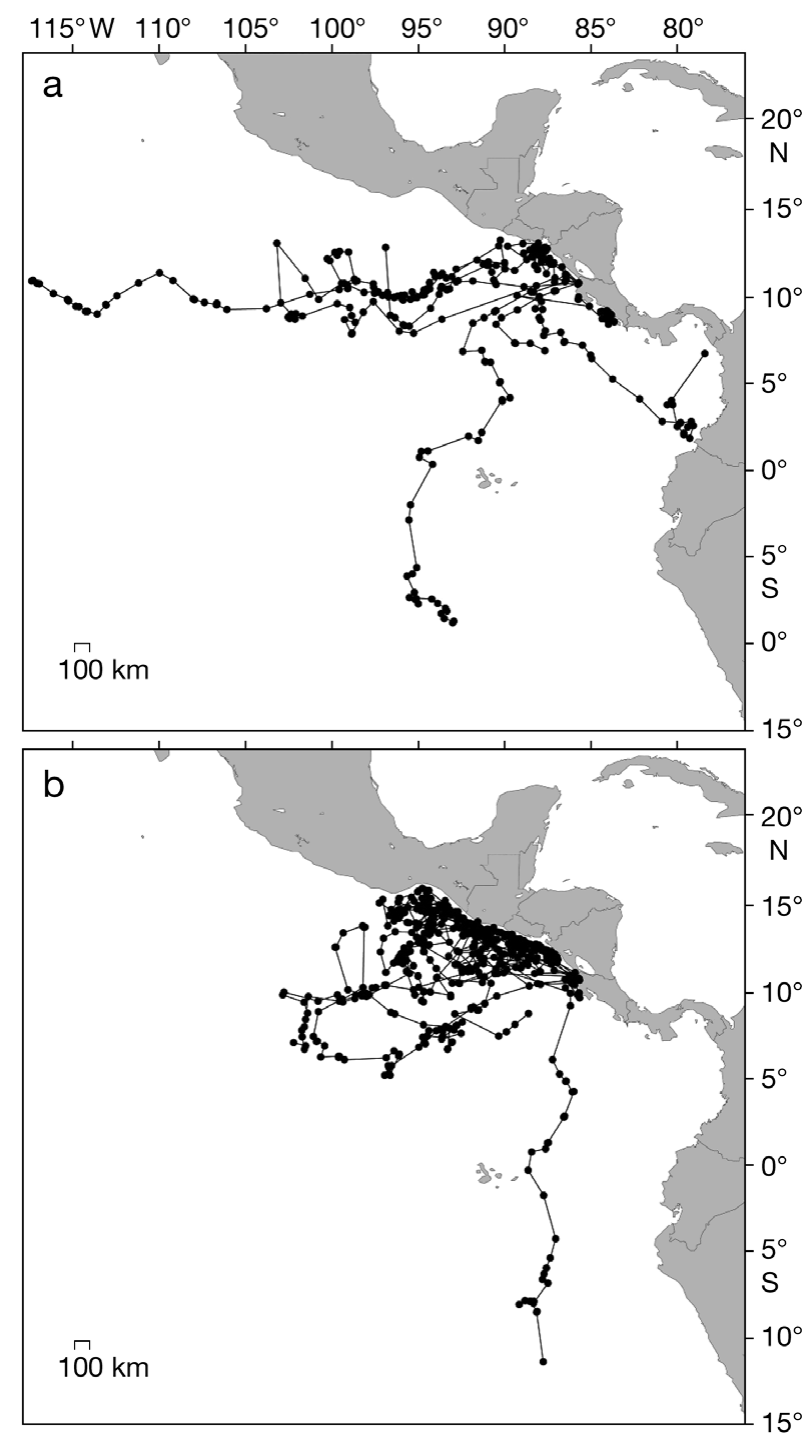

Fig. 1. Lepidochelys olivacea. Post-nesting migrations of 20 female olive ridleys during (a) 1990-1991 and (b) 1991-1992

less than during the second year (1991-1992; mean \pm $\mathrm{SD}=4422 \pm 1534 \mathrm{~km}, \mathrm{n}=11 ; t=2.06866, \mathrm{p}=0.05)$, and this difference was unrelated to transmitter duration (mean \pm SD, 1990: $207 \pm 127 \mathrm{~d}, \mathrm{n}=9$; 1991: $241 \pm 91 \mathrm{~d}$, $\mathrm{n}=11 ; t=2.10092, \mathrm{p}=0.05)$. The minimum distance travelled by males was not significantly different than the distance travelled by females during the first year, but was significantly less than the distance travelled by females during the second year $(t=2.06866, \mathrm{p}=0.05)$. The mean ROM of females ranged from 0.41 to $1.69 \mathrm{~km}$ $\mathrm{h}^{-1}\left(\right.$ mean $\left.\pm \mathrm{SE}=1.18 \pm 0.04 \mathrm{~km} \mathrm{~h}^{-1}, \mathrm{n}=20\right)$ and was not significantly different between years nor significantly different than the mean ROM of males, which ranged from 0.33 to $1.33 \mathrm{~km} \mathrm{~h}^{-1}$ (mean $\pm \mathrm{SE}=0.92 \pm$ $\left.0.10 \mathrm{~km} \mathrm{~h}^{-1}, \mathrm{n}=6 ; t=2.06390 ; \mathrm{p}=0.05\right)$.

\section{One turtle's multi-year journey}

I tracked 1 female continuously for more than $2 \mathrm{yr}$, using 2 different transmitters (7675a and 7681; Fig. 2). This turtle was captured in the Gulf of Papagayo in November 1990, was later observed nesting on Nancite Beach during the November 1990 arribada and then migrated north to an area south of the Gulf of Fonseca. She remained offshore Nicaragua and travelled $2625 \mathrm{~km}$ in $350 \mathrm{~d}$. She returned to the Gulf of Papagayo in October 1991, was recaptured nesting on Nancite Beach during the November 1991 arribada, and a new transmitter was attached. This turtle left the Gulf of Papagayo after nesting just once, and began her migration along the same route she had travelled previously. She returned to the same area offshore Nicaragua, but did not remain there.
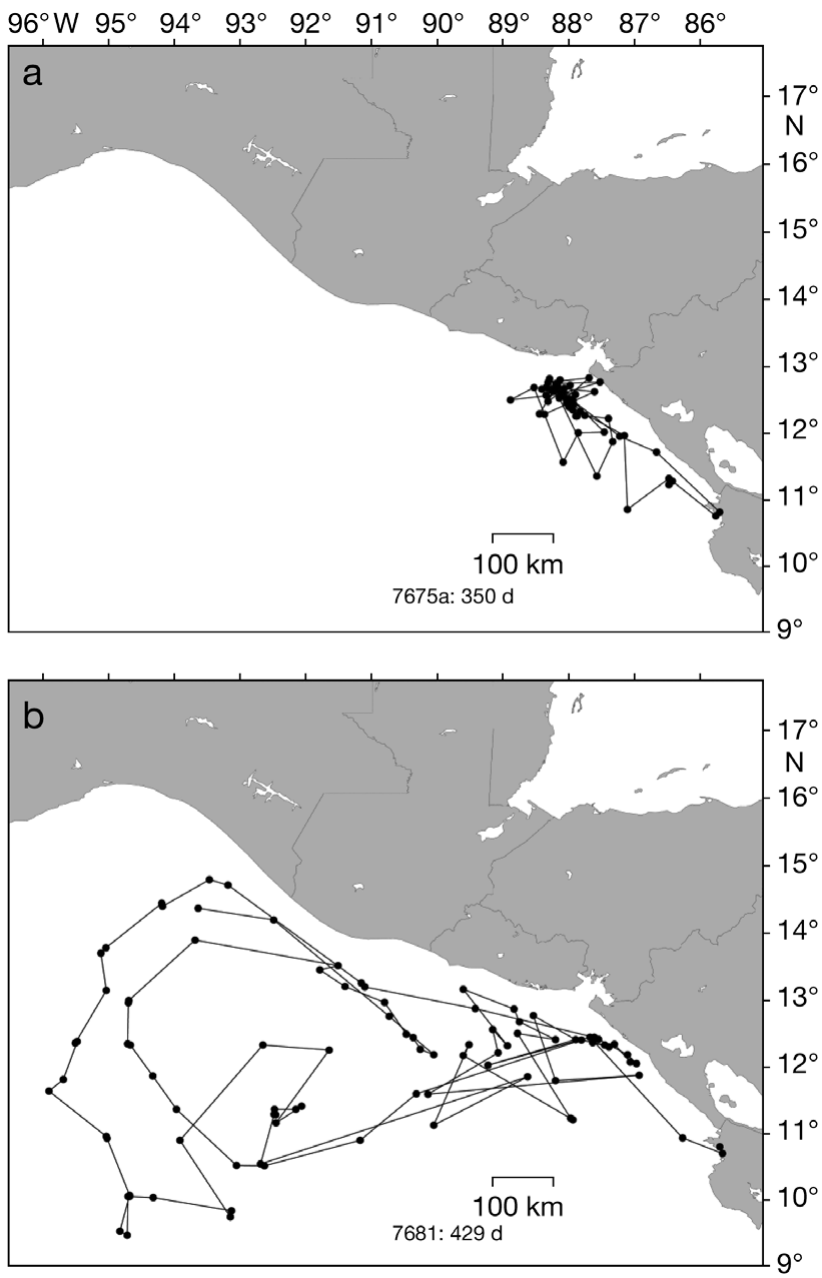

Fig. 2. Lepidochelys olivacea. Post-nesting migrations of 1 olive ridley during (a) 1990-1991 and (b) 1991-1992. Numbers below the scale bars indicate the transmitter ID and the number of days between transmitter deployment and last transmission 
Table 2. Lepidochelys olivacea. Olive ridley turtle transmitter ID, location quality indices (LQ) for locations received, minimum distance travelled, mean rate of movement (ROM) and standard error (SE) of the mean. No LQ: no location quality assigned to a turtle's position; LQ0: precision of location unknown; LQ1: precision estimated to be within $1 \mathrm{~km}$; LQ2: precision estimated to be within $350 \mathrm{~m}$; LQ3: precision estimated to be within $150 \mathrm{~m}$. For gender of turtles see Table 1. na: not available

\begin{tabular}{|lcccccccc|}
\hline ID no. & No & LQ0 & LQ1 & LQ2 & LQ3 & $\begin{array}{c}\text { Distance } \\
(\mathrm{km})\end{array}$ & $\begin{array}{c}\text { Mean ROM } \\
\left(\mathrm{km} \mathrm{h}^{-1}\right)\end{array}$ & SE \\
& LQ & & & & & & & \\
\hline 7667 & 25 & 66 & 28 & 6 & 1 & 4165 & 1.64 & 0.15 \\
7668 & 16 & 46 & 7 & 1 & 0 & 3138 & 1.47 & 0.27 \\
7669 & 4 & 23 & 1 & 0 & 0 & 438 & 0.41 & 0.14 \\
$7670 \mathrm{a}$ & 19 & 73 & 15 & 0 & 0 & 3649 & 1.29 & 0.16 \\
$7670 \mathrm{~b}$ & 4 & 51 & 28 & 40 & 14 & 5454 & 2.46 & 0.47 \\
$7671 \mathrm{a}$ & 7 & 31 & 7 & 1 & 0 & 1032 & 1.32 & 0.22 \\
$7671 \mathrm{~b}^{\mathrm{a}}$ & 1 & 7 & 1 & 0 & 0 & 471 & 3.31 & 1.97 \\
$7672 \mathrm{a}$ & 11 & 12 & 2 & 0 & 0 & na & na & na \\
$7672 \mathrm{~b}$ & 3 & 5 & 1 & 0 & 0 & na & na & na \\
$7672 \mathrm{c}$ & 12 & 17 & 1 & 0 & 0 & 1173 & 0.33 & 0.06 \\
$7673 \mathrm{a}$ & 11 & 27 & 5 & 0 & 0 & 1572 & 1.37 & 0.23 \\
$7673 \mathrm{~b}$ & 12 & 13 & 0 & 0 & 0 & 1977 & 1.06 & 0.27 \\
$7674 \mathrm{a}$ & 8 & 27 & 6 & 0 & 0 & 662 & 0.41 & 0.11 \\
$7674 \mathrm{~b}$ & 18 & 31 & 1 & 0 & 0 & 2817 & 0.67 & 0.18 \\
$7675 \mathrm{a}{ }^{\mathrm{b}}$ & 11 & 63 & 7 & 2 & 0 & 2625 & 0.57 & 0.09 \\
$7675 \mathrm{~b}$ & 7 & 14 & 5 & 1 & 0 & 1973 & 1.16 & 0.24 \\
7676 & 0 & 2 & 0 & 0 & 0 & na & na & na \\
7677 & 31 & 91 & 10 & 1 & 0 & 7457 & 0.84 & 0.08 \\
$7678 \mathrm{a}$ & 11 & 34 & 7 & 0 & 0 & 2510 & 1.30 & 0.25 \\
$7678 \mathrm{~b}$ & 13 & 18 & 3 & 0 & 0 & 3914 & 0.99 & 0.34 \\
7679 & 10 & 40 & 10 & 3 & 0 & 3328 & 1.69 & 0.23 \\
$7680 \mathrm{a}$ & 20 & 56 & 7 & 0 & 0 & 3758 & 0.99 & 0.13 \\
$7680 \mathrm{~b}$ & 20 & 19 & 4 & 0 & 0 & 2418 & 1.33 & 0.28 \\
$7681^{\mathrm{b}}$ & 28 & 112 & 24 & 8 & 0 & 8025 & 1.25 & 0.13 \\
7682 & 20 & 31 & 12 & 1 & 0 & 3715 & 1.34 & 0.14 \\
7683 & 22 & 85 & 6 & 2 & 0 & 4769 & 1.12 & 0.11 \\
7685 & 20 & 67 & 23 & 1 & 0 & 4511 & 1.29 & 0.12 \\
7686 & 22 & 65 & 7 & 0 & 0 & 3554 & 0.90 & 0.15 \\
7687 & 27 & 59 & 12 & 0 & 0 & 5590 & 1.43 & 0.10 \\
7688 & 28 & 54 & 12 & 1 & 0 & 3319 & 1.25 & 0.21 \\
7689 & 35 & 100 & 27 & 2 & 0 & 5561 & 1.17 & 0.09 \\
a The transmitters are believed to have been brought onboard a vessel during \\
the study & & & & & & & \\
${ }^{\mathrm{T}}$ These & 2 transmitters & were attached to the same turtle, & during 2 & different \\
years & & & & & & & & \\
\hline & & & & & & & & \\
\hline
\end{tabular}

\section{DISCUSSION}

These data represent one of the largest long-term data sets of internesting movements (Plotkin et al. 1995, 1996, 1997) and post-reproductive migrations collected for olive ridleys. Tracking studies of other sea turtle species have documented long-distance post-reproductive movements to foraging habitats occurring within a few weeks post-breeding/nesting, and lasting as long as 3 to 4 mo (Plotkin et al. 1996, Luschi et al. 1998, Godley et al. 2002, Hays et al. 2002, McMahon et al. 2007, Cuevas et al. 2008, Seminoff et al. 2008). Therefore, the data reported in the present study represent turtles that had completed their post-reproductive migrations to foraging habitats.

Unlike many sea turtles that migrate from their breeding ground to a single foraging area, where they remain more or less resident until the next breeding season (Broderick et al. 2007), ETP olive ridleys are highly migratory, swimming more or less continuously and feeding as they travel throughout the ETP. Although feeding was not observed during this study, I presume the turtles were feeding during migrations, and that brief stops along the route were positive indications of resource availability. The slow swimming speeds, continual movements, tendency to spend short periods of time in an area before moving elsewhere, lack of migratory corridors leading towards common feeding grounds and migratory flexibility in response to changing environmental conditions characterise the olive ridley as a nomadic migrant.

Instead, she migrated farther north towards the Gulf of Tehuantepec, swam farther offshore than before and travelled a minimum distance of $8025 \mathrm{~km}$ in $429 \mathrm{~d}$, nearly 3 times the distance travelled in the previous year. Her mean rate of movement increased from $0.57 \mathrm{~km} \mathrm{~h}^{-1}$ in Year 1 to $1.25 \mathrm{~km} \mathrm{~h}^{-1}$ in Year 2 . During the nesting season of the second year (June to December 1992), she did not return to nest on Nancite Beach, nor is there any indication from the data that she nested on any other beach. The last location received for this turtle was on 3 January 1993 from offshore southwest Mexico.
The nomadic behaviour of ETP olive ridleys, and their distribution reported in this and other studies (Swimmer et al. 2006, Eguchi et al. 2007), parallels the largescale variability and unpredictability of the ETP. This dynamic ecosystem is dominated by seasonal and interannual variability (Reilly \& Fiedler 1994). Periodic El Niño-Southern Oscillation events occur regularly and cause significant shifts in oceanographic patterns and spatio-temporal distribution of resources (Fiedler 1992). During an El Niño, the winds that drive ocean circulation patterns and create upwelling are less intense and allow warmer water from the western Pacific 
to move towards the eastern Pacific and displace highly productive cold upwelled water. Areas frequented by turtles overlapped with areas of upwelling. More specifically, these areas included the Middle American Trench from the Gulf of Tehuantepec (Mexico), south to the Gulf of Papagayo (Costa Rica); the Costa Rica Dome, a semi-permanent cyclonic eddy along $10^{\circ} \mathrm{N}$; and the divergent current present between the westward flowing North Equatorial Current and eastward flowing North Equatorial Countercurrent.

An El Niño occurred in the ETP in 1991 (Monastersky 1993) in the midst of this study, and differences in the turtles' migration patterns were apparent, as predicted by Swimmer et al. (2006). The striking variation in the migration pattern of the female that was tracked for 1 yr prior to El Niño and 1 yr during El Niño, illustrates well the turtle's response to warming in the ETP. Collectively, the females were distributed primarily north of Costa Rica, from the Gulf of Tehuantepec to the Gulf of Fonseca during El Niño. One explanation for this distribution pattern lies in the unique topography of this region and its impact on air and ocean circulation. When surface waters of the ETP warm during El Niño and upwelling is less prevalent, seasonal wind-induced upwelling continues to occur from the Gulf of Tehuantepec in the north, south to the Gulfs of Papagayo (Costa Rica) and Panama (Stumpf \& Legeckis 1977, McCreary et al. 1989). These seasonal wind events occur annually between November and April (the number and intensities vary) when high pressure systems develop in the Gulf of Mexico and continue south towards Central America. As these fronts move south, their associated winds are obstructed from the Pacific by the mountain chain that extends from Mexico into Central America, with the exception of 3 breaks in the chain located adjacent to the Gulfs of Tehuantepec, Papagayo and Panama. The winds funnel through these mountain passes, strengthen in intensity as they blow offshore and create an ageostrophic current which forces coastal upwelling and large cyclonic and anticyclonic gyres (Stumpf \& Legeckis 1977, McCreary et al. 1989). These strong winds, often referred to as 'Tehuantepecers' in Mexico and 'Papagayos' in Costa Rica, produce mesoscale surface circulation features, or gyres. Satellite images have documented the offshore movements of these gyres up to several hundred $\mathrm{km}$ from the coast, and have shown that they persist for several weeks to months (Stumpf \& Legeckis 1977). These patches of cold, nutrient-rich upwelled water provide important resources that likely attract and concentrate olive ridleys and other marine pelagics.

The migration patterns of turtles tracked in the present study affirm past speculation (Cornelius \& Robinson 1986) that ETP olive ridleys spend their adult life in oceanic waters. For many years, life in the pelagic zone was believed to be an adaptation unique only to leatherback sea turtles Dermochelys coriacea (Hendrickson 1980). The results of the present study also dismiss past speculation that post-nesting solitary nesting olive ridleys are not highly migratory and may reside near the breeding grounds (Cornelius \& Robinson 1986). I tracked 2 solitary nesting olive ridleys, and both travelled to oceanic waters, far from land. It is important to note that not all olive ridleys are nomadic, highly migratory oceanic migrants. In other oceans, olive ridleys occupy neritic waters (McMahon et al. 2007, Whiting et al. 2007) and do not undertake the extensive migrations documented in the present study. Thus, broad generalisations regarding the migratory behaviour of all olive ridleys should not be drawn from the results of my study. Interestingly, the migratory behaviour of ETP olive ridleys is also in stark contrast to a congener, the Kemp's ridley turtle Lepidochelys kempii, a coastal migrant with notable gender-specific differences: females migrate far distances from the nesting beach, whereas males reside offshore the nesting beach year-round (Shaver et al. 2005, Seney \& Landry 2008, Shaver \& Rubio 2008).

Recent speculation on the potential impacts of climate change suggests disadvantageous consequences for sea turtles at sea and on land where the gender of offspring is determined by the incubation temperature of the eggs (Fuentes et al. 2010, Witt et al. 2010). Results from the present study, coupled with the reproductive plasticity of olive ridleys in this region (Bernardo \& Plotkin 2007), suggest that ETP olive ridleys will be resilient to shifts in food availability arising from fluctuating ocean temperatures and changes in nesting beach suitability arising from sea-level rise. The impacts of climate change on olive ridleys in the ETP are therefore predicted to be less severe than they may be for less behaviourally plastic sea turtles.

Acknowledgements. I am grateful for support from the US National Science Foundation (grants BNS-9000075 and BNS8819940 to D. Owens), the Texas A\&M Sea Grant College Program, and the US Fish and Wildlife Service. I thank the Area de Conservacíon Guanacaste for allowing me to conduct fieldwork at the Nancite Beach Research Station and R. Blanco, who facilitated field logistics and permits. Special thanks to D. Owens and R. Byles, who provided support and ideas that contributed greatly to this project. I also acknowledge $\mathrm{T}$. Amos for help with distance calculations, the many volunteers who assisted in the field, and anonymous reviewers whose comments improved this manuscript. The Maptool program was used to create the maps in this paper. Maptool is a product of www.seaturtle.org. The animal use protocol for this research was approved by the Texas A\&M University Laboratory Animal Care Committee, and the work was conducted under US Fish and Wildlife Service Endangered Species Permit PRT-689914. 


\section{LITERATURE CITED}

Alerstam T, Hedenström A, Åkesson S (2003) Long-distance migration: evolution and determinants. Oikos 103: $247-260$

Argos (1984) Location and data collection satellite system user's guide. Service Argos, Toulouse

Bernardo J, Plotkin PT (2007) An evolutionary perspective on the arribada phenomenon and reproductive behavioural polymorphism of olive ridley sea turtles (Lepidochelys olivacea). In: Plotkin PT (ed) Biology and conservation of ridley sea turtles. Johns Hopkins University Press, Baltimore, MD, p 59-87

Broderick AC, Coyne MS, Fuller WJ, Glen F, Godley BJ (2007) Fidelity and overwintering of sea turtles. Proc Biol Sci 274:1533-1538

Cornelius SE, Robinson DC (1986) Post-nesting movements of female olive ridley turtles tagged in Costa Rica. Vida Silvestre Neotrop 1:12-23

Craig P, Parker D, Brainard R, Rice M, Balazs G (2004) Migrations of green turtles in the central South Pacific. Biol Conserv 116:433-438

- Cuevas E, Abreu-Grobois FA, Guzmán-Hernández V, Liceaga-Correa MA, van Dam RP (2008) Post-nesting migratory movements of hawksbill turtles Eretmochelys imbricata in waters adjacent to the Yucatan Peninsula, Mexico. Endang Species Res 10:123-133

Dean W (1997) The distribution and biology of nomadic birds in the Karoo, South Africa. J Biogeogr 24:769-779

> Eguchi T, Gerrodette T, Pitman RL, Seminoff JA, Dutton PH (2007) At-sea density and abundance estimates of the olive ridley turtle Lepidochelys olivacea in the eastern tropical Pacific. Endang Species Res 3:191-203

Fiedler PC (1992) Seasonal climatologies and variability of eastern tropical Pacific surface waters. NOAA Tech Memo NOAA-TM-NMFS-SWFSC-109

Franks NR, Fletcher CR (1983) Spatial patterns in army ant foraging and migration: Eciton burchelli on Barro Colorado Island, Panama. Behav Ecol Sociobiol 12: 261-270

> Fuentes MMPB, Limpus CJ, Hamann M, Dawson J (2010) Potential impacts of projected sea-level rise on sea turtle rookeries. Aquat Conserv Mar Freshw Ecosyst 20:132-139

Godley BJ, Richardson S, Broderick AC, Coyne MS, Glen F, Hays GC (2002) Long-term satellite telemetry of the movements and habitat utilisation by green turtles in the Mediterranean. Ecography 25:352-362

Godley BJ, Blumenthal JM, Broderick AC, Coyne MS, Godfrey MH, Hawkes LA, Witt MJ (2008) Satellite tracking of sea turtles: Where have we been and where do we go next? Endang Species Res 4:3-22

> Hays GC, Broderick AC, Godley BJ, Lovell P, Martin C, McConnell BJ, Richardson S (2002) Biphasal long distance migration in green turtles. Anim Behav 64:895-898

- Hays GC, Houghton JD, Isaacs C, Kin RS, Lloyds C, Lovell P (2004) First records of oceanic dive profiles for leatherback turtles, Dermochelys coriacea, indicate behavioural plasticity associated with long-distance migration. Anim Behav 67:733-743

Hendrickson JR (1980) The ecological strategies of sea turtles. Am Zool 20:597-608

Klimley AP, Jorgensen SJ, Muhlia-Melo A, Beavers SC (2003) The occurrence of yellowfin tuna (Thunnus albacares) at Espiritu Santo Seamount in the Gulf of California. Fish Bull 101:684-692

Luschi P, Hays GC, Del Seppia C, Marsh R, Papi F (1998) The navigational feats of green sea turtles migrating from
Ascension Island investigated by satellite telemetry. Proc Biol Sci 265:2279-2284

Luschi P, Hays GC, Papi F (2003) A review of long-distance movements by marine turtles, and the possible role of ocean currents. Oikos 103:293-302

McCreary JP, Hyong SL, Enfield DB (1989) The response of the coastal ocean to strong offshore winds: with application to circulations in the Gulfs of Tehuantepec and Papagayo. J Mar Res 47:81-109

McCullough DR (1985) Long range movements of large terrestrial mammals. Contrib Mar Sci 27 (Suppl):444-465

> McMahon CR, Bradshaw CJA, Hays GC (2007) Satellite tracking reveals unusual diving characteristics for a marine reptile, the olive ridley turtle Lepidochelys olivacea. Mar Ecol Prog Ser 329:239-252

> Monastersky R (1993) Defying predictions, El Niño still simmers. Sci News 143:292-293

Morreale SJ, Plotkin PT, Shaver DJ, Kalb HJ (2007) Adult migration and habitat utilization: ridley turtles in their element. In: Plotkin PT (ed) Biology and conservation of ridley sea turtles. Johns Hopkins University Press, Baltimore, MD, p 213-230

Owens DW (1993) The research vessel Gyre cruise in the eastern tropical Pacific. Mar Turtle Newsl 62:8-9

Plotkin PT (1998) Interaction between behaviour of marine organisms and the performance of satellite transmitters: a marine turtle case study. Mar Technol Soc J 32:5-9

Plotkin PT (2003) Adult migrations and habitat use. In: Lutz PL, Musick JA, Wyneken J (eds) The biology of sea turtles, Vol II. CRC Press, Boca Raton, FL, p 225-241

Plotkin PT, Byles RA, Rostal DC, Owens DW (1995) Independent vs. socially facilitated migrations of the olive ridley, Lepidochelys olivacea. Mar Biol 122:137-143

Plotkin PT, Owens DW, Byles RA, Patterson R (1996) Departure of male olive ridley turtles (Lepidochelys olivacea) from a nearshore breeding area. Herpetologica 52:1-7

Plotkin PT, Rostal DC, Byles RA, Owens DW (1997) Reproductive and developmental synchrony in female Lepidochelys olivacea. J Herpetol 31:17-22

Reilly SB, Fiedler PC (1994) Interannual variability of dolphin habitats in the eastern tropical Pacific. I: Research vessel surveys, 1986-1990. Fish Bull 92:434-450

> Roshier DA, Reid JRW (2003) On animal distributions in dynamic landscapes. Ecography 26:539-544

> Seminoff JA, Zárate P, Coyne M, Foley DG, Parker D, Lyon BN, Dutton PH (2008) Post-nesting migrations of Galápagos green turtles Chelonia mydas in relation to oceanographic conditions: integrating satellite telemetry with remotely sensed ocean data. Endang Species Res 4: $57-72$

Seney EE, Landry AM (2008) Movements of Kemp's ridley sea turtles nesting on the upper Texas coast: implications for management. Endang Species Res 4:73-84

> Shaver DJ, Rubio C (2008) Post-nesting movement of wild and head-started Kemp's ridley sea turtles Lepidochelys kempii in the Gulf of Mexico. Endang Species Res 4:43-55

Shaver DJ, Schroeder BA, Byles RA, Burchfield PM, Pena J, Marquez R, Martinez HJ (2005) Movements and home ranges of adult male Kemp's ridley sea turtles (Lepidochelys kempii) in the Gulf of Mexico investigated by satellite telemetry. Chelonian Conserv Biol 4:817-827

Stumpf HG, Legeckis RV (1977) Satellite observations of meso-scale eddy dynamics in the eastern tropical Pacific Ocean. J Phys Oceanogr 7:648-658

Swimmer Y, Arauz R, McCracken M, McNaughton L and others (2006) Diving behaviour and delayed mortality of olive ridley sea turtles Lepidochelys olivacea after their 
release from longline fishing gear. Mar Ecol Prog Ser 323: 253-261

Troëng S, Dutton PH, Evans D (2005a) Migration of hawksbill turtles Eretmochelys imbricata from Tortuguero, Costa Rica. Ecography 28:394-402

Troëng S, Evans DR, Harrison E, Lagueux CJ (2005b) Migration of green turtles Chelonia mydas from Tortuguero, Costa Rica. Mar Biol 148:435-447

Whiting SD, Long JL, Coyne M (2007) Migration routes and foraging behaviour of olive ridley turtles Lepi-

Editorial responsibility: Brendan Godley,

University of Exeter, Cornwall Campus, UK dochelys olivacea in NE Australia. Endang Species Res 3:1-9

Witt MJ, Broderick AC, Johns DJ, Martin CS, Penrose R, Hoogmoed MS, Godley BJ (2007) Prey landscapes help identify potential foraging habitats for leatherback turtles in the NE Atlantic. Mar Ecol Prog Ser 337:231-243

Witt MJ, Hawkes LA, Godfrey MH, Godley BJ, Broderick AC (2010) Predicting the impacts of climate change on a globally distributed species: the case of the loggerhead sea turtle. J Exp Biol 213:901-911

Submitted: October 15, 2007; Accepted: September 7, 2010 Proofs received from author(s): November 7, 2010 